\title{
Pemenuhan Gizi Mahasiswa Indekos dan Indekos Pada Masa Pandemi Covid-19
}

\author{
Rahmi Susanti ${ }^{*}$, Alfi Cahya Pratiwi ${ }^{2}$, Ghina Athika ${ }^{3}$ \\ ${ }_{1,2,3}$ Ilmu Kesehatan Masyarakat, Fakultas Kesehatan Masyarakat, Universitas Mulawarman \\ e-mail*: rahmi.susanti@fkm.unmul.ac.id
}

\begin{abstract}
ABSTRAK
Gizi ganda merupakan masalah kesehatan yang sangat mendasar bagi kehidupan dan akan berdampak kepada kualitas sumber daya generasi penerus. Kekurangan gizi mengakibatkan tidak optimalnya pertumbuhan fisik dan kecerdasan, serta kelebihan gizi mengakibatkan timbulnya penyakit degeneratif, Gizi lebih dan gizi kurang pada remaja Indonesia tahun 2013 mencapai 26,9\% dan 11,1\%, kondisi tersebut menunjukkan remaja indonesia termasuk mahasiswa indekos belum memenuhi kebutuhan gizi mereka. Sebagian besar prilaku konsumsi mahasiswa indekos cenderung tidak teratur dan jauh dari ukuran sehat terutama saat masa pandemi covid-19, hal itu mempengaruhi status gizi mereka. Tujuan penelitian ini untuk mengetahui perbedaan pemenuhan gizi mahasiswa indekos dan non-indekos selama masa pandemi covid-19 di Fakultas Kesehatan Masyarakat Universitas Mulawarman. Penelitian analitik komparatif dengan desain cross sectional. Sampel berjumlah 22 mahasiwa indekos dan 22 mahasiswa non-indekos Fakultas Kesehatan Masyarakat Universitas Mulawarman. Data diperoleh dengan wawancara menggunakan form food recall 1x24 hours serta dianalisis dengan uji Mann Whitney $(\alpha=0.05)$. Penelitian menunjukkan tidak ada perbedaan pemenuhan energi $(\mathrm{p}=0.329)$, protein $(\mathrm{p}=0.782)$, lemak $(\mathrm{p}=0.077)$, dan karbohidrat $(\mathrm{p}=0.303)$ antara mahasiswa indekos dan non-indekos Fakultas Kesehatan Masyarakat Universitas Mulawarman. Tidak ada perbedaan pemenuhan gizi mahasiswa indekos dan non-indekos selama masa pandemi covid-19 di Fakultas Kesehatan Masyarakat Universitas Mulawarman.
\end{abstract}

Kata kunci: Gizi, Mahasiswa, Indekos, Pandemi Covid-19.

\begin{abstract}
The double burden of malnutrition was a very basic health problem and would impact to the quality of the next generations. Undernutrition would impact to the un-optimal physical and intelligence growth. Overnutrition would impact to degenerative diseases. Overnutrition and Undernutrition among Indonesian adolescents in 2013 was $26.9 \%$ and $11.1 \%$, these conditions indicate that Indonesian adolescents including boarding students were not fulfilling their necessities of nutrition. Most of student's consumption behavior whose living in boarding house were irregular and far from healthy, specially during the pandemic covid-19, it would affect to their nutritional status. The purpose of this study is to analyze the different nutrition fulfillment of boarding and non-boarding students of Faculty of public Health Mulawarman University during the pandemic covid-19. Comparative analytic research with cross sectional design. The sample were 22 boarding students and 22 non-boarding students of the Public Health Faculty Mulawarman University. Data obtained by interview using food recall form $1 x$ 24 hours and analyzed with Mann Whitney Test $(\alpha=0.05)$. The study showed there was no difference in the fulfillment of energy $(p=0.329)$, protein $(p=0.782)$, fat $(p=0.077)$, and carbohydrates $(p=$ 0.303 ) between boarding and non-boarding students. There was no difference in the fulfillment of nutrition for boarding and non-boarding students during the pandemic covid-19period at the Faculty of Public Health, Mulawarman University.
\end{abstract}

Keywords: nutrition, students, boarding house, pandemic covid-19 


\section{PENDAHULUAN}

Masalah yang memprihatinkan di Indonesia saat ini adalah masalah gizi ganda, yakni masalah kekurangan gizi yang berakibat tidak optimalnya pertumbuhan fisik dan kecerdasan, dan di sisi lain masalah kelebihan gizi yang berakibat timbulnya penyakit degeneratif, seperti hipertensi, jantung, diabetes, dan stroke. Masalah gizi sendiri termasuk ke dalam masalah kesehatan yang sangat mendasar bagi kehidupan, karena bila suatu generasi mengalami masalah gizi maka dampaknya adalah kualitas sumber daya generasi penerus [1].

Angka kegemukan dan kurus pada dewasa muda di Indonesia pada tahun 2013 masingmasing mencapai $26,9 \%$ dan $11,1 \%$ [2]. Berdasarkan penelitian yang dilakukan oleh Rokhmah et al. (2016) didapatkan bahwa mayoritas mahasiswa yang tinggal di asrama/kos memiliki konsumsi energi yang inadekuat (71\%), mayoritas mahasiswa yang tinggal di asrama/kos memiliki konsumsi protein yang inadekuat (67\%), mayoritas mahasiswa yang tinggal di asrama/kos memiliki konsumsi lemak yang inadekuat $(71 \%)$, serta mayoritas mahasiswa yang tinggal di asrama/kos memiliki konsumsi karbohidrat yang inadekuat (67\%) [3]. Penelitian lain menunjukkan bahwa konsumsi protein, zat besi, karbohidrat dan daging pada responden kost lebih rendah dibandingkan dengan responden rumah sendiri [4].

Kondisi tersebut menunjukkan makanan yang dikonsumsi masyarakat (remaja) terutama mahasiswa indekos belum sesuai kebutuhan. Menurut Novitasari (2014), sebagian besar perilaku atau pola konsumsi mahasiswa yang tinggal di kost dan asrama cenderung tidak teratur dan jauh dari ukuran sehat [4]. Hal ini disebabkan oleh banyak faktor antara lain kurangnya kepedulian dan pengetahuan tentang pola makan yang baik, aktivitas yang padat, kesulitan ekonomi, dan lain sebagainya. Selain itu sebagian besar mahasiswa tinggal di kost dan berada jauh dari keluarga, karena itu tidak ada yang mengatur pola makan mereka sehari-hari, mahasiswa yang tinggal di kost cenderung memilih makanan mereka sendiri dan jarang memikirkan komposisi yang baik berdasarkan zat gizi yang diperlukannya [5].

Disamping itu, dengan kondisi Pandemi Covid-19 seperti saat ini membuat mahasiswa mengalami perubahan aktivitas fisik dan penerapan prinsip gizi seimbang dimana mereka harus membatasi aktivitas di luar tempat tinggalnya sehingga akan mempengaruhi status gizi mereka [3]. Tujuan penelitian ini yaitu mengetahui perbedaan pemenuhan gizi mahasiswa yang menetap di kost atau jauh dari keluarga dengan mahasiswa yang berada dirumah bersama keluarga selama masa pandemi di Fakultas Kesehatan Masyarakat Universitas Mulawarman.

\section{BAHAN DAN METODE}

Penelitian ini merupakan studi analitik komparatif dengan desain cross sectional. Penelitian ini berlangsung pada 20 November hingga 4 Desember 2020 di Universitas Mulawarman. Populasi penelitian ini yaitu seluruh mahasiswa Fakultas Kesehatan Masyarakat Universitas Mulawarman yang dibagi menjadi 2 kelompok yaitu mahasiswa indekos (mahasiswa yang tidak tinggal dengan keluarga) dan mahasiswa non-indekos (mahasiswa yang tinggal dengan keluarga). Teknik sampling menggunakan Simple Random Sampling dengan Sampel penelitian sebesar 22 orang mahasiswa tiap kelompok. Besar sampel pengujian hipotesis untuk dua proporsi populasi tersebut dihitung melalui rumus sebagai berikut [6]:

$$
n=\frac{\left\{Z_{1-\frac{\alpha}{2}} \sqrt{2 P(1-P)}+Z_{1-\beta} \sqrt{P_{1}\left(1-P_{1}\right)+P_{2}\left(1-P_{2}\right)}\right\}^{2}}{\left(P_{1}-P_{2}\right)^{2}}
$$


P1 sebesar 0,5217 didapatkan dari proporsi mahasiswa indekos dengan frekuensi konsumsi yang tidak terpenuhi dan P2 sebesar 0,1304 merupakan proporsi mahasiswa non-indekos dengan frekuensi konsumsi yang tidak terpenuhi Muharni et al. (2015). Nilai P merupakan rata-rata kedua proporsi sampel penelitian terdahulu dengan $1-\beta=80 \%$ [7].

Penelitian ini terdapat 4 variabel yaitu variabel pemenuhan energi, variabel pemenuhan karbohidrat, variabel pemenuhan protein, dan variabel pemenuhan lemak. Data diperoleh dari wawancara terstruktur kepada responden secara online menggunakan form food recall $1 \times 24$ hours.

Dilakukan dua analisis yakni univariat dan bivariat. Analisis univariat dilakukan dengan tujuan menggambarkan karakteristik responden secara umum yang disajikan dalam bentuk tabel dan kemudian dianalisis menggunakan uji Mann Whitney dengan tujuan membuktikan hipotesis perbedaan pemenuhan gizi antar kelompok dengan tingkat kesalahan yang digunakan adalah $\alpha=$ 0.05 .

\section{A. Hasil}

\section{HASIL DAN PEMBAHASAN}

\section{Analisis Univariat}

Analisis univariat digunakan untuk melihat gambaran karakteristik responden. Hasil analisis univariat disajikan dalam bentuk tabel

Tabel 1. Karakteristik Responden

\begin{tabular}{lcc}
\hline \multicolumn{1}{c}{ Variabel } & Frekuensi $(\mathbf{n}=\mathbf{4 4})$ & Persentase $(\boldsymbol{\%})$ \\
\hline Umur & 4 & \\
18 & 2 & 9.1 \\
19 & 4 & 4.5 \\
20 & 11 & 9.1 \\
21 & 19 & 25.0 \\
22 & 4 & 43.2 \\
23 & & 9.1 \\
Jenis Kelamin & 6 & \\
Laki-laki & 38 & 13.6 \\
Perempuan & & 86.4 \\
Aktivitas Fisik & 6 & 13.6 \\
Sangat Ringan & 21 & 47.7 \\
Ringan & 15 & 34.1 \\
Sedang & 2 & 4.5 \\
Berat & & \\
IMT & 7 & 15.9 \\
Kurus & 29 & 65.9 \\
Normal & 8 & 18.2 \\
Gemuk & &
\end{tabular}

Berdasarkan Tabel 1. didapatkan mayoritas mahasiswa Fakultas Kesehatan Masyarakat Universitas Mulawarman berusia 22 tahun (43.2\%) dimana usia termuda mahasiswa adalah usia 18 tahun dan usia tertua mahasiswa adalah 23 tahun. Selain itu, didapatkan pula mayoritas mahasiswa Fakultas Kesehatan Masyarakat Universitas Mulawarman berjenis kelamin perempuan $(86.4 \%)$.

Tabel 1. Juga menunjukkan sebagian besar aktivitas fisik mahasiswa Fakultas Kesehatan Masyarakat Universitas Mulawarman berada dalam kategori ringan (47.7\%) disusul dengan kategori sedang $(34.1 \%)$ dan hanya sebagian kecil yang berada dalam kategori berat $(4.5 \%)$. 
Selain itu, lebih dari setengah mahasiswa telah memiliki status gizi yang tergolong normal (65.9\%), namun masih terdapat mahasiswa yang tergolong kurus (15.9\%) dan gemuk (18.2\%).

\section{Analisis Bivariat}

Analisis bivariat menggunakan uji Mann Whitney untuk menguji hipotesis dan melihat perbedaan pemenuhan gizi antara mahasiswa yang menetap di kost atau jauh dari keluarga dengan mahasiswa yang berada dirumah bersama keluarga.

Tabel 2. Pemenuhan Energi, Protein, Lemak dan Karbohidrat Antara Mahasiswa Indekos Dan Non-Indekos Fakultas Kesehatan Masyarakat Universitas Mulawarman

\begin{tabular}{lccccccc}
\hline \multicolumn{1}{c}{ Variabel } & \multicolumn{2}{c}{ Indekos } & \multicolumn{2}{c}{ Non-Indekos } & \multicolumn{2}{c}{ Total } & \multirow{2}{*}{-value } \\
& $\mathbf{n = 2 2}$ & $\mathbf{\%}$ & $\mathbf{n = 2 2}$ & $\mathbf{\%}$ & $\mathbf{n = 4 4}$ & $\mathbf{\%}$ & \\
\hline Pemenuhan Energi & & & & & & & \\
$\quad$ Kurang & 3 & 13.6 & 3 & 13.6 & 6 & 13.6 & 0.329 \\
$\quad$ Cukup & 8 & 36.4 & 12 & 54.5 & 20 & 45.5 & \\
$\quad$ Berlebih & 11 & 50.0 & 7 & 31.8 & 18 & 40.9 & \\
$\begin{array}{l}\text { Pemenuhan Protein } \\
\quad \text { Kurang }\end{array}$ & 4 & 18.2 & 6 & 27.3 & 10 & 22.7 & \\
$\quad$ Cukup & 12 & 54.5 & 7 & 31.8 & 19 & 43.2 & 0.782 \\
$\quad$ Berlebih & 6 & 27.3 & 9 & 40.9 & 15 & 34.1 & \\
Pemenuhan Lemak & & & & & & & \\
$\quad$ Kurang & 8 & 36.4 & 14 & 63.6 & 22 & 50.0 & 0.077 \\
$\quad$ Cukup & 8 & 36.4 & 5 & 22.7 & 13 & 29.5 & \\
$\quad$ Berlebih & 6 & 27.3 & 3 & 13.6 & 9 & 20.5 & \\
Pemenuhan Karbohidrat & & & & & & & \\
$\quad$ Kurang & 11 & 50.0 & 7 & 31.8 & 18 & 40.9 & 0.303 \\
$\quad$ Cukup & 4 & 18.2 & 6 & 27.3 & 10 & 22.7 & \\
$\quad$ Berlebih & 7 & 31.8 & 9 & 40.9 & 16 & 36.4 & \\
\hline
\end{tabular}

Berdasarkan Tabel 2. didapatkan mayoritas mahasiswa indekos dalam memenuhi kebutuhan energi berada dalam kategori berlebih (50\%) dan untuk mahasiswa non-indekos dalam memenuhi kebutuhan energi berada dalam kategori cukup (54.5\%), namun hasil uji Mann Whitney menunjukkan bahwa tidak terdapat perbedaan pemenuhan energi yang signifikan antara mahasiswa indekos dan non-indekos selama masa pandemi $(\mathrm{p}=0.329)$. Didapatkan pula mayoritas mahasiswa indekos dalam memenuhi kebutuhan protein berada dalam kategori cukup (54.5\%) dan untuk mahasiswa non-indekos dalam memenuhi kebutuhan protein berada dalam kategori berlebih (40.9\%), namun hasil uji Mann Whitney menunjukkan bahwa tidak terdapat perbedaan pemenuhan protein yang signifikan antara mahasiswa indekos dan non-indekos selama masa pandemi $(\mathrm{p}=0.782)$. Berdasarkan hasil wawancara, makanan yang dikonsumsi mahasiswa untuk memenuhi kebutuhan protein adalah ikan, telur, ayam, susu, kacang tanah, tahu, dan tempe.

Tabel 2. Juga menunjukkan mayoritas mahasiswa indekos dalam memenuhi kebutuhan lemak berada dalam kategori kurang (36.4\%) dan cukup (36.4) serta untuk mahasiswa nonindekos dalam memenuhi kebutuhan lemak berada dalam kategori kurang (63.6\%), namun hasil uji Mann Whitney menunjukkan bahwa tidak terdapat perbedaan pemenuhan lemak yang signifikan antara mahasiswa indekos dan non-indekos selama masa pandemi $(\mathrm{p}=0.077)$. Berdasarkan hasil wawancara, makanan yang dikonsumsi mahasiswa untuk memenuhi kebutuhan lemak adalah mie instan, gorengan, makanan ringan (snack), ikan, telur, dan kacang tanah. Didapatkan pula mayoritas mahasiswa indekos dalam memenuhi kebutuhan karbohidrat berada dalam kategori kurang $(50.0 \%)$ dan untuk mahasiswa non-indekos dalam memenuhi kebutuhan karbohidrat berada dalam kategori berlebih (40.9\%), namun hasil uji Mann Whitney menunjukkan bahwa tidak terdapat perbedaan pemenuhan karbohidrat yang signifikan antara 
mahasiswa indekos dan non-indekos selama masa pandemi $(\mathrm{p}=0.303)$. Berdasarkan hasil wawancara, makanan yang dikonsumsi mahasiswa untuk memenuhi kebutuhan karbohidrat adalah nasi, mie instan, dan roti.

\section{B. Pembahasan}

Dimasa pandemi COVID-19 sangat penting untuk menjaga pola aktivitas fisik yang baik serta asupan makanan yang dikonsumsi dikarenakan kedua hal tersebut sangat berpengaruh terhadap imunitas seseorang sehingga mampu terhindar dari berbagai serangan penyakit ataupun virus lainnya. Faktor olahraga sangat besar pengaruhnya agar imunitas tubuh selalu terjaga.

Menurut Gibney (2009) dalam penelitian Muharni et al. (2015) aktivitas fisik adalah bentuk perilaku manusia yang meliputi semua gerak tubuh dimulai dari gerakan kecil hingga berpartisipasi dalam lari maraton. Individu yang mempunyai aktivitas yang lebih besar membutuhkan makanan lebih banyak untuk menghasilkan energi [7]. Untuk meningkatkan energi yang menunjang aktivitasnya, orang yang aktif tidak hanya mengandalkan makanan yang tinggi kalori, tetapi kaya akan zat gizi. Berdasarkan Tabel 1. sebagian besar aktivitas fisik mahasiswa Fakultas Kesehatan Masyarakat Universitas Mulawarman berada dalam kategori ringan $(47.7 \%)$ disusul dengan kategori sedang $(34.1 \%)$ dan hanya sebagian kecil yang berada dalam kategori berat $(4.5 \%)$. Olahraga yang baik dilakukan untuk menjaga imunitas tubuh adalah melakukan olahraga dengan intensitas sedang namun durasi yang lebih lama.

Pada umumnya, orang Indonesia makan tiga kali sehari, yaitu sarapan pagi, makan siang, dan makan malam. Menurut Masrikhiyah (2020), siswa yang terbiasa sarapan memiliki peluang lebih besar dalam meningkatkan prestasi belajarnya [8]. Mengurangi konsumsi makanan baik kuantitas dan kualitas menyebabkan gangguan proses metabolisme dalam tubuh yang tentu saja akan menyebabkan penyakit [9]. Secara tidak langsung status gizi dipengaruhi oleh beberapa faktor di antaranya usia, jenis kelamin, dan latihan fisik. Ketiga faktor tersebut mempengaruhi tingkat kebutuhan gizi dan dengan demikian mempengaruhi keadaan nutrisi. Berdasarkan Tabel 2 lebih dari setengah mahasiswa telah memiliki status gizi yang tergolong normal (65.9\%), namun masih terdapat mahasiswa yang tergolong kurus (15.9\%) dan gemuk (18.2\%). Menurut Riyadi (2006) dalam penelitian Novitasari (2014) status gizi dipengaruhi oleh pola konsumsi, penyerapan (absorpsi), dan penggunaan (utilization) zat gizi makanan [4]. Dengan menilai status gizi seseorang atau sekelompok orang maka dapat diketahui apakah seseorang atau sekelompok orang tersebut status gizinya baik ataukah tidak baik.

Frekuensi makan yang baik hendaknya dimulai dari sarapan pagi sebelum beraktivitas, makan siang sebelum lapar dan makan malam sebelum tidur. Sarapan sangat dibutuhkan oleh manusia untuk beraktivitas sejak pagi hingga petang. Sepertiga kebutuhan energi disuplai dari sarapan, sisanya dari asupan makan siang dan malam. Sarapan bukan hanya makan pagi, tetapi kebutuhan gizi perlu diperhatikan baik karbohidrat, protein, lemak, vitamin dan mineral [9]. Berdasarkan hasil food recall $1 \times 24$ hours diketahui bahwa sumber protein, lemak, dan karbohidrat yang dikonsumsi oleh mahasiswa indekos maupun mahasiswa non-indekos seperti ikan, telur, ayam, sayuran tumis maupun berkuah, mie instan, kacang tanah, tahu, tempe, dan nasi putih.

Pemenuhan energi merupakan total asupan makanan maupun minuman selama satu hari dan merupakan respon seseorang terhadap makanan sebagai kebutuhan vital bagi kehidupan. Pada penelitian ini kebutuhan energi berdasarkan hasil uji statistik menunjukkan bahwa tidak terdapat perbedaan yang signifikan antara mahasiswa yang tinggal di indekos dan non-indekos selama masa pandemi ( $\mathrm{p}=0.329$ ). Penelitian sejalan dilakukan oleh Bening (2014), didapatkan bahwa $60 \%$ dari seluruh responden belum memiliki asupan energi yang cukup [11]. Sebagian besar

JIGK Vol. 02, No. 02, Februari 2021: $36-42$ 
mahasiswi hidup sendiri, sebanyak 75\% mahasiswi gizi dan 77.5\% mahasiswi hukum tinggal di kos, sedangkan 25\% mahasiswi gizi dan 23.5\% mahasiswi hukum tinggal di rumah. Bening (2014) mengasumsikan bahwa seseorang yang tinggal di kos mengupayakan sendiri makanan yang dikonsumsi [12]. Mereka mengalami ketidakmampuan dalam menyediakan makanan seharihari sehingga mereka harus membeli di warung atau rumah makan, maka makanan yang dikonsumsi tidak beragam. Berbeda dengan mereka yang tinggal di rumah, karena diasumsikan bahwa dengan tinggal dirumah asupannya lebih terjaga, lebih sehat, baik variasi maupun ketersediannya pun juga mencukupi. Berdasarkan wawancara food recall $1 \times 24$ hours yang dilakukan peneliti, terdapat mahasiswa tidak melakukan sarapan maupun sarapan dengan makanan yang tidak beragam, hal ini dapat menjadi penyebab kurangnya pemenuhan energi mahasiswa. Menurut Khomsan (2005) dalam Perdana \& Hardinsyah (2013), sarapan akan memberikan asupan zat gizi yang diperlukan tubuh, seperti protein, lemak, vitamin, dan mineral [12]. Ketersediaan zat gizi ini penting untuk berfungsinya proses fisiologis dalam tubuh.

Pemenuhan protein pada penelitian ini berdasarkan hasil uji statistik menunjukkan bahwa tidak terdapat perbedaan yang signifikan antara mahasiswa indekos dan non-indekos selama masa pandemi ( $\mathrm{p}=0.782$ ). Menurut Yoris et al. (2016) dalam penelitiannya, konsumsi protein hewani dilakukan dalam jumlah yang sedikit/rendah dan tidak teratur dikarenakan terdapat $46 \%$ responden tidak tinggal bersama orangtua atau indekos [13]. Pemenuhan pangan sumber protein hewani bukan hal yang mudah bagi responden karena kesibukan tugas dan kegiatan perkuliahan, walaupun sebenarnya sumber protein hewani yang terpenuhi baik akan berpengaruh terhadap peningkatan perhatian dan kemampuan untuk belajar lebih baik.

Penyumbang energi terbesar dibandingkan zat gizi lain adalah lemak karena dapat menyumbang energi sebesar 9 kkal dari 1 gram lemak, tetapi konsumsi lemak harian tidak boleh melebihi 30\% dari total energi yang dianjurkan [14]. Pada penelitian ini, pemenuhan lemak berdasarkan hasil uji statistik menunjukkan bahwa tidak terdapat perbedaan yang signifikan antara mahasiswa indekos dan non-indekos selama masa pandemi $(\mathrm{p}=0.077)$.

Karbohidrat merupakan zat gizi yang sangat efisien untuk dimetabolisme menjadi energi, oleh karena itu makanan yang mengandung karbohidrat merupakan sumber energi yang paling baik [15]. Konsumsi makanan yang mengandung karbohidrat yang tidak tercukupi dapat mengakibatkan menurunnya simpanan glikogen dalam otot dan hati. Penurunan simpanan glikogen akan menurunkan daya tahan dan performa [16]. Nilai yang terkandung dalam 1 gram karbohidrat menghasilkan energi sebesar $4 \mathrm{kkal}$. Pada penelitian ini, hasil uji statistik menunjukkan bahwa tidak terdapat perbedaan pemenuhan karbohidrat yang signifikan antara mahasiswa indekos dan non-indekos selama masa pandemi $(\mathrm{p}=0.303)$.

\section{KESIMPULAN}

Berdasarkan penelitian ini dapat disimpulkan bahwa tidak terdapat perbedaan pemenuhan energi, protein, lemak, dan karbohidrat yang signifikan antara mahasiswa indekos dan nonindekos selama masa pandemi Covid-19.

\section{SARAN}

Disarankan kepada mahasiswa/i yang masih bertahan di indekos/ asrama selama masa pandemi tetap menjaga asupan nutrisi yang seimbang dan selalu berupaya melakukan Protokol Kesehatan baik di dalam maupun di luar tempat tinggal. 


\section{UCAPAN TERIMAKASIH}

Ucapan terimakasih kami berikan kepada seluruh responden yang bersedia terlibat dalam penelitian ini, bagian kemahasiswaan Fakultas Kesehatan Masyarakat yang membantu dalam memberikan peneliti data mahasiswa yang masih bertahan tinggal di indekos/ asrama selama masa pandemi dan seluruh rekan rekan lain yang tidak dapat kami sebutkan satu persatu.

\section{DAFTAR PUSTAKA}

[1] Pratiwi, A. C., Sari, D. W. and Aliajania, F: Tempat Makan Pendeteksi Kandungan Gizi Dan Jumlah Kalori, 2018

[2] Balitbangkes: Riset Kesehatan Dasar, 2013

[3] Rokhmah F, Muniroh L, Nindya TS. Hubungan Tingkat kecukupan energi dan zat gizi makro dengan status gizi siswi SMA di Pondok pesantren Al-Izzah Kota batu. Media Gizi Indonesia. 2016;11(1):94-100.

[4] Novitasari D. Perbedaan Pola Makan Dan Status Gizi Pada Mahasiswa Kost Dan Rumah Sendiri Yang Sedang Mengalami Stres (Doctoral dissertation, Universitas Brawijaya).

[5] Putri NR. Perbedaan status gizi antara mahasiswa yang tinggal di tempat kost dan rumah sendiri. SKRIPSI-2014. 2014 May 13.

[6] Lemeshow S, Hosmer DW, Klar J, Lwanga SK. Besar sampel dalam penelitian kesehatan. Yogyakarta: Gajah Mada University. 1997.

[7] Muharni M, Mairyiani H, Ryanti S. Perbedaan Pola Makan, Aktivitas Fisik Dan Status Gizi Antara Mahasiswa Indekos Dan Tidak Indekos Poltekkes Kemenkes Riau. Jurnal Proteksi Kesehatan. 2015;4(1).

[8] Masrikhiyah R. Pengaruh Kebiasaan Sarapan Dan Status Gizi Remaja Terhadap Prestasi Belajar. Jurnal Ilmiah Gizi dan Kesehatan (JIGK). 2020 Aug 31;2(01):23-7.

[9] Almatsier S. Prinsip dasar ilmu gizi, PT. Gramedia Pustaka Utama, Jakarta. 2010.

[10] Hardinsyah: Pentingnya Sarapan Sebelum Sekolah, Kemendikbud Pergizi Pangan Indonesia, 2015

[11] Bening S, Margawati A. Perbedaan Pengetahuan Gizi, Body Image, Asupan Energi Dan Status Gizi Pada Mahasiswi Gizi Dan Non Gizi Universitas Diponegoro (Doctoral dissertation, Diponegoro University).

[12] Perdana F, Hardinsyah H. Analisis jenis, jumlah, dan mutu gizi konsumsi sarapan anak Indonesia. Jurnal gizi dan Pangan. 2013 Nov 29;8(1):39-46.

[13] Yoris, L., Tiven, N. C. and Pattisinay, S. V: Studi Tentang Pola Konsumsi Pangan Sumber Protein Hewani Asal Ternak Pada Mahasiswa Fakultas Pertanian UNPATTI, Jurnal Makila, 9(1), pp. 108-115, 2016

[14] Soetjiningsih S. Tumbuh kembang remaja dan permasalahannya. Sagung Seto. Jakarta. 2004;320.

[15] Kementerian Kesehatan Republik Indonesia: Pedoman Gizi Olahraga Prestasi, Jakarta, 2014. [16] Welis W, Sazeli RM. Gizi untuk aktifitas fisik dan kebugaran. 